\title{
SOCJOLOGICZNE WIDZENIE FILMU I KINA. ARTYKULACJE I PRAKTYKI W POLU SOCJOLOGII FILMU I KINA
}

\begin{abstract}
Streszczenie
W artykule podjęto próbę rekonstrukcji kształtowania się pola socjologii filmu i kina na podstawie analizy porównawczej ważnych, zagranicznych i polskich prac mieszczących się w ramach opisywanej subdyscypliny. Wśród nich znajdują się: pionierskie rozprawy oraz badania dotyczące kina i filmu, socjologiczne postulaty i programy badawcze, studia socjologiczne, opracowania poświęcone socjologii filmu i kina. Główny cel stanowiło uporządkowanie i podsumowanie dziedzictwa wąskiej dyscypliny socjologii filmu i kina, ujęcie pewnych praktyk, orientacji i nurtów badawczych. Autorka ukazała także obszar badań poświęcony instytucjom filmowym jako słabo reprezentowany w praktyce badań socjologicznych w Polsce i za granicą. Inspirację teoretyczną dla nakreślonych poszukiwań stanowi teoria praktyki naukowej Pierre'a Bourdieu, a także pojęcia: habitus, pole oraz kapitał.

Slowa kluczowe: socjologia filmu, socjologia kina, film, kino, kinematografia
\end{abstract}

\section{WPROWADZENIE}

Tytułowe socjologiczne widzenie filmu i kina odnosi się do przekonania o odmienności postrzegania (i badania) kina oraz filmu przez socjologię. Wraz z rozwojem kina oraz nauk o filmie kształtowała się odrębna, choć nieautonomiczna subdy-

* Dr, Instytut Socjologii, Katedra Socjologii Sztuki i Edukacji; e-mail:ewelina.wejbert@uni.lodz.pl 
scyplina socjologii kultury - socjologia filmu i kina. Współcześnie nie cieszy się ona takim zainteresowaniem naukowym jak kilka dekad wcześniej. Powyższa uwaga dotyczy szczególnie socjologicznych badań nad instytucją kina oraz nad filmem kinowym, nietelewizyjnym. Jakie są tego powody? Oprócz różnorodnych wpływów naukowych, społecznych, ekonomicznych, kulturowych, politycznych, technicznych można by wymienić inne, które potencjalnie odpowiadaja, w mniejszym czy większym stopniu, za taki stan rzeczy.

Celem artykułu jest syntetyczne ujęcie pewnych praktyk, orientacji, nurtów badawczych oraz przedstawienie konkluzji nad wyodrębnionym dziedzictwem opisywanej subdyscypliny. Jest to wiedza budowana w oparciu o zasadę refleksyjności [Bourdieu, Wacquant 2001]. Mówiąc językiem Bourdieu, z gąszczu różnorodnych publikacji możemy wyłonić pewne dominujące reguły („logiki rządzące polem”) i praktyki w polu subdyscypliny. Przedmiotem oglądu są prace inicjujące, wyodrębniające, rozwijające kształt pola socjologii kina i filmu oraz studia poświęcone socjologii filmu i kina: 1) postulaty, programy głoszone przez socjologów lub wyraźnie wyartykułowane jako socjologiczne ${ }^{1} ; 2$ ) socjologiczne prace i badania dotyczące problematyki filmu i kina²; 3) studia dotyczące subdyscypliny.

Proponowany zarys pola socjologii filmu i kina uwzględnia socjologię ,projektowaną" oraz empiryczna, stosowaną. Jest to analiza wewnętrzna, gdyż autorka nie bierze pod uwagę przestrzeni i zależności pomiędzy polami różnych nauk o filmie i kinie ani związków socjologii z nimi (historia i teoria filmu, filozofia filmu, estetyka filmu, psychologia filmu). $Z$ tego powodu brak w tekście rozważań z historii myśli o fenomenie kina i filmu czy odniesień do filozoficznych poglądów dotyczących roli filmu wobec kultury i społeczeństwa i vice versa (obszar psychologii i socjologii filmu). Warto podkreślić, że ,społeczna myśl o kinie czy filmie" jest rozproszona (fragmentarycznie dostępna w różnych antologiach) i co najważniejsze - uprawiana przez teoretyków, historyków, krytyków kina czy filmoznawców. Osobną sprawę stanowi wkład teoretyków i krytyków filmu (takich jak np. Hugo Münsterberg, Rudolf Arnheim, Karol Irzykowski, Béla Balázs, Bertold Brecht, Walter Benjamin, Gilles Deleuze, Aleksander Jackiewicz, Arnold Hauser i wielu innych) w rozwój subdyscypliny socjologii filmu i kina, której to kwestii w tym artykule również nie podejmowano.

Inspirację teoretyczną dla nakreślonych poszukiwań stanowić mogą koncepcje Pierre'a Bourdieu [Bourdieu 2008, 2009] czy Bruna Latoura [Latour

${ }^{1}$ Mieści się tu program Socjologia kina J.S. Bystronia, Socjologia filmu K. Żygulskiego oraz Socjologiczne widzenie kina S. Salzmana.

2 Są to przede wszystkim prace socjologów, a także inne studia uznane za socjologiczne, np. pionierskie dla socjologii kina (E. Kiep-Altenloh, L. Skoczylasa). 
2010] - oponenta Bourdieu w dyskusji. Niniejszy szkic można traktować jako przyczynek do dalszych, szerzej zakrojonych badań pola nauki (w tym przypadku socjologii filmu i kina). Autorka posiłkuje się teorią praktyki naukowej Pierre'a Bourdieu [Bourdieu, Wacquant 2001; Bourdieu 2008], jego sądami na temat funkcji socjologii oraz miejsca w polu nauk czy rekonstrukcji społecznej genezy myśli społecznej. W rozważaniach Bourdieu nad socjologią jako nauką istotny wymiar stanowią praktyki ujmowane za pomocą pojęć pola (arena walk o kapitał), kapitału (zasoby funkcjonujące jako społeczny stosunek władzy) i habitusu graczy (schematy działania, postrzegania i oceny wytworzone w wyniku działania w różnych pozycjach w historii pól). Autorka nie prowadzi analizy, podążając za agentami czy graczami pola nauki, jak zalecał Bourdieu [Bourdieu 2008]. Wymagałoby to dogłębnego prześledzenia życiorysów i dokonań autorów, ich relacji, związków z innymi graczami w polu.

W pierwszej części artykułu podjęto refleksję nad historia, dorobkiem omawianej socjologii, aby określić ontologiczny status socjologii filmu i kina oraz wskazać jej specyficzne, empiryczne zainteresowania, do czego nawiązuje już sam tytuł tekstu. Druga część niniejszego szkicu dotyczy źródeł powstania i rozwoju rodzimej socjologii filmu, co istotne - źródeł całkiem odmiennych niż w krajach zachodniej Europy i w Stanach Zjednoczonych. Dalej, w trzeciej części tekstu chronologicznemu i ogólnemu przeglądowi poddano proces wyłaniania się instytucji filmowych (i agentów pola) w polu kinematografii. Wskazano także obiektywne problemy w badaniu instytucji filmowych przez socjologów. Taka linia wywodu wynika z programu badawczego subdyscypliny, rozdźwięku między artykulacją w polu naukowym a praktyką badawczą. Jest to również znaczące dla podejścia Pierre'a Bourdieu do nauki, traktowanej przez niego jako pola określonych praktyk społecznych. Namysł nad opisywanym polem naukowym wymaga rekonstrukcji dominującego dyskursu naukowego (nurty, orientacje w polu socjologii filmu i kina), jak i celów zrealizowanych i niezrealizowanych, obszarów zaniedbanych w polu subdyscypliny (tzw. białe plamy). Socjologowie niezwykle rzadko badają instytucje kinowe i filmowe [Ethis 2007: 100-130]. Autorka próbuje dociec, dlaczego tak się dzieje.

\section{SOCJOLOGICZNE ZAINTERESOWANIA KINEM}

Pierwsza na świecie dysertacja z socjologii kina Zur Soziologie des Kino: Die Kino-Unternehmung und die Sozialen Schichten Ihrer besucher obroniona została w 1913 roku przez Emilie Kiep-Altenloh, ekonomistkę i socjolog, a w rok później wydana drukiem. W tym samym roku (1913) polski pedagog, krytyk 
literacki i teatralny Ludwik Skoczylas przeprowadził sondaż wśród lwowskich uczniów uczęszczających do kina. Z perspektywy czasu należy docenić nie tylko samą rozprawę E. Kiep-Altenloh, lecz i postawę autorki, która była świadoma oddziaływania kinematografii na widzów, ale nie deprecjonowała roli masowej rozrywki, co stanowiło wówczas wyjątek. W większości tekstów naukowych $\mathrm{z}$ tego okresu uważano bowiem, że kino to marnowanie czasu wolnego robotników [por. Bevans 1913; Bocheńska 1975; Helman 1994 i wskazana tam literatura]. Socjologiczne ujęcie kina zaproponowane przez Emilie Kiep-Altenloh dotyczyło dwóch elementów komunikacji: producentów kina i publiczności. Przedmiotem jej ilościowych badań z 1912/1913 roku były kinowe upodobania i zwyczaje widzów w Mannheim (2400 kwestionariuszy ankiety). Ważne kategorie tej socjologicznej analizy widzów to: płeć, wiek, status społeczny, stan cywilny, zawód, religijność, poglądy polityczne i kinowe zwyczaje. Incydentalne badania publiczności kinowej w Anglii i w USA opublikowano ponad dekadę później. Studia nad widownią kin kontynuowano w tych krajach przez wiele dziesięcioleci. Prowadzono je nawet w okresie drugiej wojny światowej i tuż po jej zakończeniu [por. Box, Moss 1943; Manvell 1946; Mayer 1946; Lazarsfeld 1947; Mayer 1948]. W Polsce pojawiły się dopiero w latach 50. i 60. ubiegłego wieku.

Jak powyżej wskazano, najstarsze studia uznane za socjologiczne przedstawiały socjograficzne opisy miast, kin, ekonomiki pola produkcji kinowej oraz publiczności. Co istotne, badania nad fenomenem kina wyprzedzały teorie na ten temat, a zwłaszcza refleksję dotyczącą ,wpływu kina na masy ludzkie”, podkreślanego zarówno przez prasę [por. Gierszewska 2005], jak i krytyków [zob. Balazs 1957: 23]. Publikacje nie były wolne od moralizowania i przekonania o złym wpływie kina, szczególnie na młodzież. Ta przesłanka (czy reguła w grze) stała się siłą aktywizującą amerykańskie środowisko naukowe. Przykład może stanowić sytuacja, gdy Herbert Blumer, obok Roberta Parka ze szkoły chicagowskiej i innych socjologów z uniwersytetów amerykańskich, został powołany do Komitetu Badań Edukacyjnych w latach 1929-1932. Bourdieu nazywa ten rodzaj władzy kapitałem administracyjnym [por. Sztandar-Sztanderska 2010: 66]. Komitet Badań Edukacyjnych zajmował się kwestiami szeroko pojętego wychowania i edukacji, dysponował kapitałem symbolicznym i zasobami ekonomicznymi (na badania i publikacje). To właśnie wtedy, od trzeciej dekady XX wieku obserwujemy systematyczne zainteresowanie kinem przez socjologów [por. Dale 1933; Peters 1933; Renshaw, Miller, Marquis 1933]. Regułą dominującą w polu socjologii stała się „,podejrzliwość” w stosunku do kina jako instytucji życia społecznego. Blumer w pracy Movies and Conduct przedstawił analizę pisemnych autobiografii widzów kinowych, potwierdzając ówczesne przekonania o oddzia- 
ływaniu filmów na zachowania i postawy ludzkie [Blumer 1933a]. Biograficzne podejście badawcze Blumera w Wielkiej Brytanii reprezentował Jacob Mayer, czemu dał wyraz w studiach nad reakcjami dzieci i dorosłych wobec kina. Paul Lazarsfeld analizował wówczas relacje między przestępczością a prezentowaną w filmach tego okresu brutalnością [Darmas 2014: 30].

W Polsce środowisko socjologów pozostawało dość oporne wobec fenomenu kina, mimo że pierwsze krajowe opracowanie pt. Socjologia kina opublikowane zostało już w 1919 roku. Praktyki badawcze rodzimych socjologów skupiały się wokół kwestii narodowych, położenia społecznego chłopstwa i proletariatu miejskiego, a także oświaty i wychowania. W latach 30 . ubiegłego wieku o wpływie kina na młodzież pisał pedagog, teoretyk i krytyk filmu, Bolesław Lewicki [Lewicki 1935], psycholog Leopold Blaustein [Bocheńska 1975: 245-264]. W Europie powojennej ta kwestia nadal przykuwała uwagę socjologów [Mayer 1946: 58-144 i wskazana tam literatura oraz raporty]. Miało to także miejsce w okresie wzmożonego zainteresowania socjologią kina i filmu - w szóstej i siódmej dekadzie XX wieku [por. Morin 1975]. Wypada również podkreślić, że związki między treściami zawartymi w filmach a przemocą i przestępczością jako zjawiskami społecznymi to wattek analiz podejmowany nie tylko w latach 30. ubiegłego wieku. Temat zyskał na sile wraz z rozwojem telewizji, wideo, gier i Internetu.

Szereg uwag krytycznych pod adresem kina formułowała szkoła frankfurcka piętnująca zjawiska kultury masowej, w kinie upatrująca instrumentu manipulacji i ujarzmiania społeczeństwa przez system kapitalistyczny i przemysł kulturalny. Filozofowie, teoretycy kultury, socjologowie, tacy jak Max Horkheimer i Theodor Adorno w Dialektyce oświecenia, opublikowanej w 1947 roku (w Polsce w 1994), atakowali różne przejawy kultury masowej, np. jazz [Horkheimer, Adorno 1994: 145-146; 154; 168], radio [Horkheimer, Adorno 1994: 169; 174; 179-180], amerykańskie reklamy i magazyny [Horkheimer, Adorno 1994: 141; $168 ; 184 ; 252]$ oraz kino, które deprecjonowali, pisząc na przykład w taki sposób: „Gdyby zamknąć większość radiostacji i kin, konsumenci może wcale nie odczuliby braku. [...] Zawodu doznaliby nie tyle entuzjaści, co ci, na których i tak wszystko się źle odbija, ci, co pozostali w tyle [...]" [Horkheimer, Adorno 1994: 158]. Niemieccy uczeni dokonywali nieusystematyzowanych analiz filmów fabularnych, o czym świadczą eseistyczne wypowiedzi (np. uwagi o zależności kina od banków, o pozornej konkurencji między produkcjami Warner Brothers i Metro Goldwyn Mayer, o ideologii kina) oraz o konkretnych filmach (np. o Dyktatorze w reż. Ch. Chaplina, o gatunkach filmowych) [Horkheimer, Adorno 1994: 157-158; 168-170]. 
W latach 40. światowe uznanie zyskał Siegfried Kracauer - niemiecki socjo$\log$, historyk i teoretyk filmowy, który na podstawie analiz filmów niemieckich z okresu 1918-1933 (ekspresjonizm) wykazał psychologiczne predyspozycje narodu do nazizmu. Jeszcze w latach 50. twórcy szkoły frankfurckiej byli zszokowani wynikami swoich studiów, gdyż nazizm okazał się postawą nadal aktualną wśród młodych ludzi. Kracauer w dziele Od Caligariego do Hitlera (1946) pisał, że film odzwierciedla mentalność narodu bardziej niż jakiekolwiek inne artystyczne środki wyrazu, bo jest dziełem zespołowym i odwołuje się do mas [Kracauer 2009: 9]. Kracauer jako socjolog i psycholog społeczny zainicjował nurt badań porównawczych nad kinematografią (produkcją) i historią. Współcześnie kontynuatorem jego teorii jest między innymi francuski historyk kina Marc Ferro [Ferro 2011]. Niemieckie kino ekspresjonistyczne było przedmiotem zainteresowań również innych badaczy. Amerykański socjolog Georg Huaco [Huaco 1965] zajął się makroekonomiczno-społeczną analizą niemieckich filmów ekspresjonistycznych z lat 1920-1931 oraz analizą realistycznych obrazów radzieckich i włoskich. Z kolei Mike Budd przyjął socjogenetyczną perspektywę oglądu ekspresjonizmu niemieckiego. W Odstonach Gabinetu dr. Caligari odrzucił interpretację Kracauera, skupiając się na relacjach pomiędzy dziełem-wytworem a siecią zależności politycznych i kulturalnych [por. Budd, w: Kurz 2008: 189-241].

Bourdieu w posłowiu do Homo Academicusa przywoływał walki we francuskim polu uniwersyteckim między dyscyplinami w polu „nauk o człowieku” [por. Bourdieu 2013: 40-47]. W polu socjologii filmu i kina reguły zmieniały się na skutek oddziaływań różnych trendów w humanistyce, zwrotów w polu nauk o kulturze. W drugiej połowie lat 60. upowszechniła się analiza filmowa traktująca kino jak ,język", co wiązało się z wpływem strukturalizmu na pole nauk o filmie. Pierwsze analizy tekstualne filmów jawiły się niczym drobiazgowe opisy kadrów, najczęściej montażu. Doprowadziły one do odkrycia zbiorów dyspozycji psychicznych widza. Z czasem semio-lingwistyczne podejście spotkało się z krytyką. W dyskursie naukowym ożyła teoria podmiotu w wersji freudowskiej, a potem lacanowskiej. „Projektor filmowy” - to pojęcie, które obejmowało projektor psychiczny (m.in. identyfikację widza z własnym spojrzeniem, przyjemność płynącą z patrzenia, podglądania). Analizy strukturalno-psychoanalityczne filmu skupiały się także na odkrywaniu struktur głębokich w obrazach (jak np. kompleks Edypa, kastracja). Psychoanalizie zawdzięczamy feministyczne analizy filmów, podkreślające rolę spojrzenia męskiego jako władczego czy popędu voyeryzmu, przekształcającego ,innego” w obiekt. Psychoanalityczne myślenie o sztuce znamionowało przełom lat 60. i 70. XX wieku. Mimo różnych innych 
istniejących teorii podmiotu psychoanaliza stała się najsilniejszą ramą teoretyczną refleksji nad kulturą [por. Žižek 2001]. Najbardziej znane socjologicznie prace na temat doświadczania odbioru filmów bazują na opisanych przez Edgara Morina mechanizmach projekcji i identyfikacji jednostki w trakcie seansu [Morin 1975]. Identyfikacja obrazów ekranowych z życiem znamionuje codzienne procesy „,projekcji - identyfikacji”. Odnajdujemy je już u samych podstaw historii percepcji filmowej (silne reakcje emocjonalne publiczności na pierwsze filmy). Wypada tu wspomnieć o dokumentach Edgara Morina i Jeana Roucha z nurtu cinéma-vérité z lat 60., które wywarły znaczny wpływ na kinematografię (nowa fala) i dokument. W Polsce program „kina prawdy” miał wpływ na niektórych dokumentalistów, co zaobserwować można w filmach Marcela Łozińskiego, Krzysztofa Kieślowskiego i wielu innych.

Ogólnie szósta i siódma dekada XX wieku jawi się jako złota era socjologii filmu i kina. Świadczy o tym obfitość prac w tym polu, a także posługiwanie się filmem jako narzędziem badawczym i formą wypowiedzi naukowej [por. Kaczmarek 2008: 169-178; Kaczmarek 2014: 145-148; 237-247]. Socjologowie w tym okresie opisywali także publiczność kinową (wedle kategorii wieku, klasy społecznej i filmowych gustów sprowadzanych do oglądanych gatunków filmowych), wykonywali analizy statystyczne kinematograficznych osiagnięć krajów i produkcji poszczególnych wytwórni. Badacze tworzyli interesujące porównania przemysłu amerykańskiego, zachodnioeuropejskiego i komunistycznego, uwzględniając system strukturalny produkcji i obiegu filmów oraz wzajemne powiązania, koszty i przychody, a niekiedy także charakterystyki publiczności [por. Jarvie 1970: 56-62; Prokop 1970 i wskazana literatura]. Współcześnie takie inicjatywy przesunęły się w kierunku studiów różnych publiczności. Pozostają rzadkością w polu socjologów kultury, podobnie jak analizy instytucji filmowych [Ethis 2007].

W latach 80. i 90. XX wieku w odniesieniu do badań filmu popularność zyskuje tradycja brytyjskich studiów kulturowych [Hall 1979; Fiske 1987, 1989]. Reprezentanci szkoły w Birmingham „na warsztat analityczny biorą" kulturę popularną, w tym seriale, telewizję; badają także różnorodne użytki audytoriów tej kultury. W Polsce publikowane są socjologiczne prace analizujące fenomen serialowych reprezentacji mediujących porządek społeczny [np. Siemieńska 1981; Gałuszka 1996; Kościelski 1987]. W polu nauk o kulturze w pierwszej połowie lat 90. XX wieku dochodzi także do „zwrotu wizualnego”, z którego wyrasta między innymi socjologia wizualna [Sztompka 2005]. Przedmiotem naukowej refleksji o filmie w kręgu badaczy wizualności staje się obraz filmowy, odtwarzanie specyfiki spojrzenia kinematograficznego. Wydaje się, że socjologia 
wizualna nie wniosła jeszcze wkładu w omawianą tu subdyscyplinę, jest raczej pewnym podejściem metodologiczno-badawczym. W rodzimej literaturze socjologicznej ma zastosowanie w odniesieniu do fotografii, wideoblogów, fotoblogów, filmu dokumentalnego [np. Sztompka 2005; Kaczmarek 2006; Olechnicki 2009; Krajewski, Drozdowski 2010], w tym także do filmu socjologicznego [Kaczmarek 2014], ale nie w stosunku do filmu (niefikcjonalnego, niedokumentalnego, kinowego). Poza zwrotem ikonicznym w latach 90. dochodzi do innego, historycznego zwrotu w humanistyce, głównie za sprawą trzytomowego dzieła Pierre'a Nory pt. Miejsca pamięci. Odtąd istotną kwestią podejmowaną w refleksji kulturoznawczej, w teorii socjologicznej oraz w badaniach stała się problematyka pamięci, a dla badaczy mediów - doświadczenie zapośredniczone medialnie [por. Kluszczyński 2008]. Zwroty w polu nauk o kulturze mają widoczny wpływ na pole omawianej tu socjologii. W humanistyce po trendzie lingwistycznym, strukturalnym, psychoanalitycznym nastapiły kolejne: ikoniczny/piktorialny, topograficzny, przedmiotowy, performatywny. Natomiast podsumowanie dotychczas wyłonionych reguł w polu praktyk empirycznych socjologii filmu może ułatwić odwołanie się do refleksji metanaukowej z okresu lat 70., która pojawiła się w dyskursie naukowym za sprawą Iana Jarviego.

Filozof filmu w obszernej rozprawie Movies and society [Jarvie 1970] zebra1 dokonania socjologów. Jarvie podawał w wątpliwość regułę dominacji problematyki kinematograficznej wśród badaczy kultury. Pisał o kinie jako o instytucji społecznej - jednej z wielu. Potępiał praktyki polegające na przejmowaniu od krytyków postawy estetycznej (wartościowanie filmów). Mechanizm ten uwidaczniał się jego zdaniem $w$ polu naukowym, w historycznie pierwszych, a potem w kolejnych socjologicznych pracach. $Z$ tego powodu krytykował znane rozprawy (np. S. Kracauera). Jarvie zarzucał różnym autorom (silnym graczom, aktorom w polu), że w analizach uwzględniali tylko dobre dzieła bądź nie ujawniali autorskich kryteriów doboru filmów. Takie tendencje można zaobserwować w szeregu prac w ciaggu następnych dekad. Wedle filozofa „słabe” filmy przechodzą taki sam proces produkcji jak inne i nie ma powodu, aby wykluczać je z analiz. Ciekawostkę może stanowić fakt, iż sam Ian Jarvie nie ustrzegł się przed tym błędem (regułą kanonicznego doboru filmów), gdyż „studiując polską kinematografię", analizował wyłącznie filmy Andrzeja Wajdy. Refleksja spod znaku Movies and society posiadała znamiona druzgocacej krytyki, bowiem Jarvie, na podstawie drobiazgowej analizy wytworów pola subdyscypliny, ogłosił, że wszystkie dotychczasowe prace mające w tytule wyrażenie „socjologia filmu” $\mathrm{w}$ istocie nią nie były. Według niego socjologowie żywili przekonanie, że ich dyscyplina powinna stawiać wobec kina szczególne, interesujące z jej punktu 
widzenia pytania, a ostatecznie koncentrowali się na kwestii wpływu filmowego (szczególnie na młodych), odbioru filmów i ich publiczności [por. Tudor 1974].

Czym zatem byłyby te szczególne pytania socjologii w reakcji na fenomen kina i filmu? Śledząc dorobek socjologów filmu i kina na świecie, można wytyczyć trzy główne nurty zainteresowań [por. Darmas 2014: 37-38]. Rysunek 1 ilustruje dotychczasowe rozważania, ujmując dwa najstarsze i główne nurty badawcze w socjologii oraz koncepcję Iana Jarviego. Tworzenie, oglądanie, doświadczanie i ocenianie filmów to pola, które składają się na program socjologii filmu Jarviego. Jego zdaniem socjolog odpowiada na cztery pytania: 1 . Kto robi filmy i dlaczego (przemysł); 2. Kto ogląda filmy i dlaczego (publiczność); 3. Co jest oglądane, jak i dlaczego? (doświadczenia); 4. Jak i przez kogo filmy są oceniane (recepcja i ocena).

RYSUNEK 1. Główne zainteresowania socjologów kinem/filmem

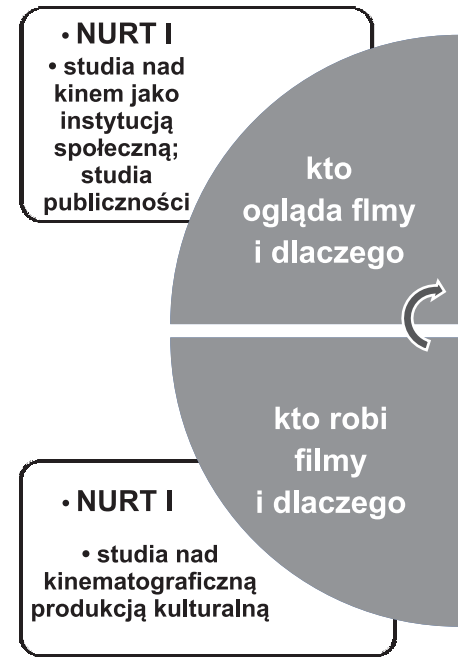

socjologia

kina

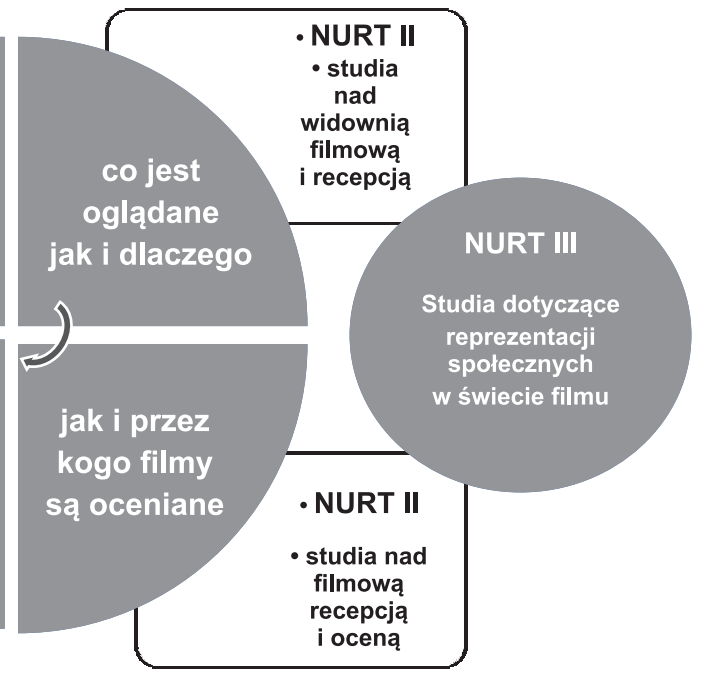

socjologia filmu

Źródło: opracowanie własne.

Nurt pierwszy to studia kinematograficzne, traktujące kino i film niczym dziedzinę produkcji kulturalnej wraz z towarzyszącymi jej aspektami socjoekonomicznymi, oraz studia postrzegające kino jako instytucję społeczną reprezentującą produkcję, ale także akcentujące kwestie związane z kulturalną i artystyczną recepcją filmu. W drugim nurcie sytuują się bardzo popularne badania dotyczące 
społecznego oddziaływania kina i filmów (szkoła chicagowska), a także tradycje brytyjskich studiów kulturowych oraz analizy wizualne filmów. Na marginesie pola zainteresowań naukowych znajduje się trzeci nurt, czyli studia dotyczące reprezentacji społecznych w świecie filmu (np. Kracauer, Ferro, Jarvie, Sorlin). W większości prace europejskie i amerykańskie dotyczyły analizy kina jako „przemysłu” oraz kwestii wpływu filmów na dzieci, młodzież, dorosłych. Studia nad obrazem rzeczywistości społecznej w filmach podejmowano rzadziej w kręgu socjologów, wykorzystując content analysis (stąd na rysunku 1 marginalna pozycja). Zaznaczyć należy, że podziały te są umowne, gdyż np. w drugim i trzecim nurcie sytuuje się kwestia doświadczeń filmowych. Oprócz zarysowanych dróg w badaniach nad kinem i filmem warto wspomnieć o wyodrębnieniu socjologii kina i socjologii filmu. Pierwsza z nich pozostaje „socjologią zewnętrzną”, druga - „socjologią wewnętrzną”. Ich obszary, pola zachodzą na siebie, wzajemnie się krzyżują, ale inne są cele i metody badań. Socjologia kina zajmuje się analizą zależności między człowiekiem a kinematografią jako instytucją społeczną, realizującą różne funkcje społeczne na rzecz jednostek, grup społecznych i mas ludzkich; wykorzystuje w tym celu różne dane statystyczne, kwestionariusze i źródła opracowane ilościowo. Socjologia filmu skupia się na metodach jakościowych, ponieważ przedmiotem swojego głównego zainteresowania czyni społeczną naturę filmu, a więc jego postrzeganie i funkcjonowanie w kulturze, oraz społeczne reprezentacje odzwierciedlone w utworach.

Inny podział zaproponował Ian Jarvie [1970], który uczęszczanie do kina czy „na film” traktuje niczym pewien typ instytucji społecznej, wyróżniając w socjologii filmu - socjologię sztuki i socjologię rozrywki [por. Esquenazi 2007].

Zarysowane pola socjologii filmu (prawa strona rysunku 1) versus socjologii kina (lewa strona rysunku 1) należy traktować jako typy idealne, bowiem w praktyce badawczej socjolog filmu korzysta z danych ilościowych, a socjolog kina, np. badający recepcję i gusta, stosuje techniki ilościowe i jakościowe. Klasyfikacja przedstawiona na rysunku 1 uwzględnia stałe praktyki badawcze (podejścia metodologiczne, przedmiot i cel badań). A jak na tym tle przedstawia się geneza i rozwój socjologii filmu w Polsce?

\section{SOCJOLOGIA KINA I FILMU W POLSCE. PIONIERZY, SOCJOLOGOWIE I INNI BADACZE}

W Polsce socjologia filmu wyodrębniła się z wiedzy o filmie, inaczej niż w krajach zachodnich, gdzie film stanowił przedmiot badań socjologicznych jeszcze przed pierwszą wojną światową. Znamienne, że pionierskie badania w kraju w dziedzi- 
nie recepcji filmu i praktyk kinowych podjął w 1913 roku wspomniany wcześniej Ludwik Skoczylas, który postanowił przeprowadzić sondaż wśród młodzieży lwowskiej na temat uczestnictwa w kinie i gustów kinowych [Bocheńska 1975: 77-84]. Jest to pierwsze znane nam w Polsce przedsięwzięcie rozpoczynające nurt badań empirycznych w sferze kultury, w tym w socjologii filmu. Autor z niechęcią traktował „kinoteatr” z uwagi na jego zły wpływ na młodzież, czemu dawał wyraz w swoich publikacjach. Od uczniów uzyskał odpowiedzi na sześć pytań dotyczących frekwencji, towarzystwa kinowego, wrażeń, upodobań, pamięci obrazu, opinii o pożyteczności lub szkodliwości kina [Bocheńska 1975: 77-84]. Chociaż Ludwik Skoczylas nie posługiwał się pojęciem socjologii filmu, to nie ma wątpliwości, że był prekursorem w tej specjalności [por. Michalewicz 1998: 92-100]. Do pionierów socjologii filmu w Polsce zaliczyć należy także filozofa i działacza oświatowego Mariana Stępowskiego [Bocheńska 1975: 84-95; 303], który w 1914 roku w „Kurierze Polskim” ogłaszał drukiem Wszechwładztwo kinematografu.

W drugiej dekadzie XX wieku polskie pole socjologii dopiero się kształtuje. Pierwsza katedra socjologii w niepodległej Polsce powstała w 1919 roku z inicjatywy Leona Petrażyckiego na Wydziale Prawa i Nauk Politycznych UW w Warszawie. W kraju, w porównaniu do Niemiec, Francji czy Wielkiej Brytanii, istniał mały kapitał państwowy (nadrzędny w ujęciu Bourdieu) i kapitał instytucjonalny. Ogólnie w II Rzeczpospolitej pozycja socjologii w polu nauk była słaba, a charakterystyczną cechą pola socjologii kina i filmu pozostawał brak autonomii. Z początkowego okresu instytucjonalizacji socjologii w państwie polskim pochodzi pierwszy rodzimy tekst o socjologii kina. Był nim wspomniany wcześniej artykuł Jana Stanisława Bystronia z 1919 roku pt. Socjologia kina. Kino było dla uczonego wynalazkiem o ogromnej sile oddziaływania na jednostkę i masy. Krytyk pisał, że dzięki „ekranowi” zmniejszył się dystans chłopa wobec innych światów społecznych, warstw społecznych, miasta i wsi. Chłop uczęszczający na projekcje filmowe stawał się „międzynarodowym turystą” [Bystroń 1919: 1]. Autor jako pierwszy w historii polskiej socjologii postulował stworzenie odrębnej dyscypliny socjologicznej, która miała przede wszystkim zajmować się badaniem wpływu kina. Program Bystronia nie przyjął się w Polsce, a jego autor również nie kontynuował tematu, poświęcając swą uwagę innym zagadnieniom (takim jak m.in.: kultura ludowa, socjologia wychowania, socjologia miasta). Generalnie społeczne oddziaływanie kina nie interesowało polskich badaczy, z wyjątkiem na przykład Floriana Znanieckiego, który zaliczał kinematograf do instytucji pośredniego wychowania [Znaniecki 1934: 303]. Metodologia badań 
kina nie rozwijała się, mimo iż Stanisław Ossowski dał jej asumpt - w rozprawie U podstaw estetyki z 1933 roku przyznał filmowi taką samą wartość jak innym sztukom. Ogólnie można zauważyć, że w dyskursie naukowym nie funkcjonowało odrębne stanowisko socjologii w stosunku do dziedzin sztuki czy do kultury masowej. Ujmowanie sztuki filmowej jako swoistego teatru uwidoczniło się w socjologicznych rozważaniach na temat sztuki sceny Aleksandra Hertza, autora Socjologii wspótczesnej (1938). W swojej kolejnej książce-Zagadnieniach socjologii teatru, wydanej we Lwowie w 1939 roku, Hertz pisał o kulcie gwiazd i przenikaniu wzorów kulturowych z ekranu do rzeczywistości [Michalewicz 1998: 244-245]. Według niego kino stanowiło użyteczną instytucję społeczna, choć jego funkcję wychowawczą w porównaniu z teatrem oceniał jako słabszą („niski wpływ uspołeczniający kina”) ${ }^{3}$.

Trudno w tym czasie wskazać inne opracowania rodzimych socjologów problematyzujące zagadnienia filmu. $\mathrm{Na}$ tym tle wybijał się w kraju postulat lwowskiego literata Stanisława Salzmana, do którego nawiązuje tytuł niniejszego artykułu. Autor przedwojennego tekstu pt. Socjologiczne widzenia kina (1936) [Bocheńska 1975], opublikowanego w czasopiśmie społeczno-kulturalnym „Sygnały”, zgłaszał propozycję badań empirycznych dotyczących filmu w aspekcie komunikacji społecznej, podkreślając potrzebę badań treści (co jest przedstawione) i formy (jak jest przedstawiane). Dzieło filmowe postrzegał dualistycznie - jako produkt artystyczny, ale i przemysłowy. W opinii Salzmana najważniejszym elementem X muzy pozostawała strona materialno-techniczna filmu. Utwór zależny od grupy ludzi, od produkcji przemysłowej, od idei oraz od potrzeb klas społecznych jawił się jako nieporównywalny z innymi dziełami sztuki pod względem związków z rzeczywistością [Bocheńska 1975: 278-281].

Charakteryzując ducha tych czasów, trzeba wyeksponować zmianę, jaka dokonała się w postrzeganiu kina: od wynalazku technicznego, nauki i rozrywki do sztuki. Wyrazem rewizji poglądów w Polsce było wydanie X Muzy Karola Irzykowskiego w 1924 roku. Artykuł Socjologiczne widzenie kina stanowi świadectwo oryginalnej koncepcji badawczej, która podobnie jak twórczość poetycka Salzmana była i pozostaje nieznana w kraju. Mówiąc o nowatorstwie koncepcji Salzmana w latach 30. XX wieku, mam na uwadze fakt, że po pierwsze, ówcze-

3 W artykule Zadania społeczne teatru [Hertz 1938] Hertz wyjaśnia pojęcie uspołecznienia: „Niemniej jednak stale zachodzi tu proces uspołecznienia się przez wspólność wzruszeń, przez poddawanie się tym samym autorytetom, przez przyjmowanie tych samych wzorów obyczajowych. Wielostronność oddziaływania teatralnego sprawia, że sięga ono do różnych stron osobowości ludzkiej, że może zaspokajać różnorodne potrzeby, dążenia kompensacyjne, nadawać formę i wyraz różnorodnym postawom i oczekiwaniom” [Hertz 1938: 32]. 
śnie żaden z socjologów w Polsce nie zajmował się naukowo kinem, filmem. Po drugie, taki program był pionierski na tle tendencji światowych w socjologii filmu i kina. Artykulacja Salzmana w „opisywanym polu” nie wpłynęła na rozwój socjologii filmu czy kina w kraju. Niebagatelną rolę odegrała tu polityka i historia ${ }^{4}$. Bourdieu powiedziałby, że Salzman nie posiadał właściwego kapitału naukowego i pozycji (wiedza oraz uznanie przyznawane przez innych naukowców), jednak wspominano go jako wybitnego intelektualistę [por. Piekarski 2007].

W Polsce powojennej socjologia filmu i kina posiadała słabą autonomię w polu nauk o filmie. Z jednej strony, dostrzegano potrzebę uprawiania socjologii stosowanej, o czym świadczy na przykład fakt, że już w 1946 roku rozpoczęły się amatorskie „badania socjologiczne” czasopisma „Film”. Organizowano wówczas sondaże dotyczące oglądalności filmów w kinach. Z drugiej strony, socjologię uznano za naukę burżuazyjną (lata 50. XX wieku). Wówczas krytycy filmowi na łamach prasy akcentowali potrzebę prowadzenia badań z dziedziny socjologii filmu [por. Michalewicz 2003: 18-20]. Liczne badania terenowe w tym czasie miały na celu realizowanie zadań użytkowych, a nie naukowych. Stawki i reguły w grze były jasne [por. Sztandar-Sztanderska 2010: 70-71]. Wiele razy w PRL-u zawieszano prace nad opracowaniem materiałów badawczych na temat odbioru filmów z powodu braku kadry i funduszy lub cenzury. W obawie przed niepożądanymi rezultatami - jak pisał Jerzy Toeplitz - badania Zygmunta Pióro nad recepcją filmów radzieckich „programowo zlikwidowano" [Michalewicz 2003: 10]. W 1951 roku wydano odgórną decyzję o zakończeniu serii badań prowadzonych od 1948 roku pod kierownictwem Z. Pióro. Oficjalnym powodem likwidacji badań były ograniczone fundusze oraz brak personelu do opracowania materiałów. Dokumentacja z wywiadów i sondaży z 1951 roku nigdy nie została poddana analizie, choć złożono ją w archiwum Państwowego Instytutu Sztuki.

Wydaje się, że w latach 50. i 60. film podejmował funkcję opisywania rzeczywistości. Fenomen socjologicznej obserwacji objawił się w dokumentach z cyklu „czarna seria”, w filmach Edwarda Skórzewskiego, Jerzego Hoffmana, Kazimierza Karabasza, a także Danuty Halladin, Krystyny Gryczełowskiej i wielu innych. Tworzono filmy dokumentalne będące swoistymi sondami czy eksperymentami socjologicznymi.

4 Stanisław Salzman (ur. ok. 1907 r. w Starym Samborze) w latach 20. studiował polonistykę na UJK we Lwowie u Juliusza Kleinera. Pracował we Lwowie jako krytyk filmowy, literat, recenzent, dziennikarz. W okresie 1936-1938 współpracował z czasopismem „Sygnały” oraz redagował dziennik „Wiek nowy”. W 1939 roku, po wkroczeniu Armii Czerwonej do miasta znalazł się w redakcji sowieckiego „Czerwonego Sztandaru”, gdzie pisał pod pseudonimem „Sulikowski”. Pod koniec 1939 roku trafił do więzienia za błędną analizę dzieł Marksa i został skazany na śmierć. Zginął w 1941 roku w Horodni. 
W szóstej i siódmej dekadzie XX wieku w Polsce zaznaczyło się wyraźne zainteresowanie kwestiami zajmującymi socjologów w krajach zachodnich, w tym m.in badaniami nad kulturą elitarna, masowa, popularną. Najbardziej znaczące projekty w polu realizował Kazimierz Żygulski. Uwaga socjologów skupiła się na problemach odbioru i analizy dzieł filmowych [por. Gałuszka, Kowalewicz 1977; Gałuszka 1984; Kowalewicz 1978; Kłoskowska, Rokuszewska-Pawełek 1977]. W dyskursie naukowym ganiono socjologów za to, że zaniedbują założenia programu badawczego socjologii filmu [Michalewicz 2003: 42], na przykład w odniesieniu do socjologicznych analiz dzieł fabularnych (rzeczywistość filmowa versus rzeczywistość społeczna $\mathrm{w}$ danym okresie). Pojawił się także postulat zawężenia pola dociekań teoretyczno-empirycznych do kwestii widowni i dzieła filmowego [Prasek 1970]. Po latach ten zabieg można interpretować jako działanie mające na celu autonomizację pola, jednak słaby habitus naukowy i symboliczny Cezarego Praska okazał się ważniejszy.

W latach 80. zainteresowanie socjologią filmu wśród polskich i zagranicznych [Jarvie 1970: 106-110] uczonych wyraźnie spadło. Uznaje się, że największe znaczenie miał w tym przypadku telewizyjny boom i związane z tym zmiany frekwencji publiczności kinowej. Sporadycznie publikowano analizy bohaterów filmowych i sondaże opisujące upodobania widzów. Brytyjskie studia kulturowe inspirowały rodzimych socjologów do badań odbioru seriali i ich treści [Siemieńska 1981; Gałuszka 1984; Kościelski 1987]. W kolejnej dekadzie socjologowie coraz rzadziej analizowali kulturę seriali [Gałuszka 1996; Jacyno 1998], zaś socjologia filmu i kina stała się dyscypliną „,porzuconą” przez badaczy. W zachodnich krajach związki socjologii i kina rozpoczęły się od empirii, by następnie (zwłaszcza w latach 70. XX wieku) przejść ku teorii. Wpłynęła na to semiotyka, teorie odwołujące się do psychoanalizy i pojęcia ideologii. Wydaje się, że ten ogólny trend miał w naszym kraju mniejszą siłę oddziaływania niż przeobrażenia społeczno-kulturowe, jakie zaszły w Polsce po 1989 roku. Słaba autonomia pola $\mathrm{w}$ poprzednich dekadach odegrała tu znaczną rolę. W efekcie klasyczna socjologia filmu i kina wyparta została przez szeroko pojętą socjologię mediów, kultury audiowizualnej.

W dorobku subdyscypliny w Polsce dominował nurt ilościowy badań nad kinem, o czym świadczą zrealizowane liczne sondaże, ankiety, wywiady kwestionariuszowe. W ciagu półwiecza dość dokładnie opisywano funkcjonalny aspekt odbioru kina czy filmu [por. Rudzki 1967; Kulik 1968; Osiński 1985; Godzic 1996]. Bardzo rzadko stosowano metody jakościowe, takie jak np. analiza recepcji dzieła i treści dokumentów pisanych. W PRL-u spodziewano się, że badania socjologiczne pozwolą uchwycić cechy widowni i oddziaływania filmów, co w efekcie 
ułatwi formowanie typu człowieka zgodnego z ideologią ustroju. Nigdy jednak $\mathrm{w}$ Polsce nie prowadzono serii badań dotyczących społecznego oddziaływania filmów, tego, co zostaje po seansach zapamiętane, a co zapomniane. Ponadto socjologowie pytali ankietowanych o częstotliwość uczęszczania na seanse kinowe, ale nie dociekali już powodów chodzenia do kina. W PRL-u okazjonalność przedsięwzięć badawczych utrudniała porównanie wniosków z badań empirycznych, śledzenie kierunku zmian. Na niekorzyść działały pewne, powszechne w tamtym czasie, praktyki organizacji badań, tj. płynność kryteriów i stosowanych terminów przez różnych badaczy oraz brak typologii metodologicznych, np. odnośnie do kategorii składu społecznego, zawodów i wykształcenia widzów kinowych, gatunków filmów czy pomiaru częstości odwiedzin kina przez widzów [zob. Michalewicz 2003: 134-145; 153-157]. Zestawiając badania receptywne różnych audytoriów i publiczności z poprzednich dekad, można zauważyć, że wywiady socjologiczne $i$ analiza tekstów pisanych nie przyniosły spodziewanych rezultatów, ani w zakresie weryfikacji teorii, ani formułowania nowych praw dotyczących recepcji sztuki filmowej. Wypada zauważyć, że socjologowie filmu na ogół nie odwoływali się do koncepcji i teorii socjologii sztuki (i vice versa). Kwestia wspólnej przestrzeni ,innych socjologii szczegółowych” z omawianą tu subdyscypliną to temat na oddzielne studium. Pobieżny ogląd uprawnia do stwierdzenia, że bardzo słabo funkcjonuje w dyskursie naukowym na przykład socjologia wizualności - filmu lub socjologia sztuki - filmu, a przecież obie socjologie (wizualna i sztuki) są polami szerszymi niż opisywana tu subdyscyplina.

Podjęty tu zarys historii pola naukowego prowokuje do zapytania: czy i kiedy socjologia filmu zdołała zaistnieć w Polsce jako odrębna subdyscyplina socjologiczna? Odpowiedź nie wydaje sięjednoznaczna, gdyż socjologia filmu uwikłana była $\mathrm{w}$ różne zależności w polu nauk o filmie i inspiracje naukowe, zarówno od strony socjologii, jak i innych nauk o kulturze. Socjologiczne zagadnienia w kraju podejmowali częściej filmoznawcy (tacy jak: Alicja Helman, Maria Kornatowska, Zygmunt Kałużyński, Jerzy Kossak i inni) niż socjologowie. Współcześnie na gruncie empirii filmoznawcy przejęli przestrzenie badań historycznie osadzone w socjologii, np. odnośnie do kina i filmu (nieserialowego) i odnośnie do badań widowni. Pole subdyscypliny nigdy nie było autonomiczne, ale w latach 70. posiadało najsilniejszą pozycję w socjologii kultury. Socjologia filmu stanowiła najlepiej rozbudowany dział socjologii kultury, głównie za sprawą Kazimierza Żygulskiego. Określił on reguły gry w polu, nakreślił program tej subdyscypliny oraz realizował liczne badania, które podobnie jak w innych krajach najczęściej koncentrowały się wokół widowni kinowej i rządzących nią praw. 
Na cztery działy dociekań badawczych socjologii filmu wedle Żygulskiego składały się: widownia, twórcy i realizatorzy, dzieło filmowe, organizacja produkcji i rozpowszechniania filmów [Żygulski 1966]. Zadaniem socjologii filmu pozostawała analiza społecznych i kulturowych uwarunkowań twórczości filmowej i jej odbioru, a także badanie społecznej recepcji filmów oraz publiczności kinowej. W opinii Żygulskiego socjolog filmu powinien, przede wszystkim, trudnić się krytyką filmową o orientacji socjologicznej, dokonując: 1) opisu sytuacji społecznych ukazywanych na przykładzie utworu filmowego; 2) konfrontacji kwestii społecznych ukazywanych w filmach z rzeczywistością społeczną; 3) porównania sytuacji społecznych ukazywanych w konkretnym utworze $\mathrm{z}$ analogicznymi okolicznościami $\mathrm{w}$ innych, artystycznych środkach wyrazu: literaturze, teatrze, malarstwie. Były to raczej postulaty niż praktyki, gdyż socjologowie filmu w PRL-u nie zajmowali się powyższymi zadaniami, wytyczonymi przez Kazimierza Żygulskiego. W III RP studium zorientowane na porównanie rzeczywistości społeczno-historycznej i filmowej okresu PRL-u w myśl programu Żygulskiego opublikował Cezary Prasek, socjolog kultury pozostający poza polem nauki [por. Prasek 1970; 2010;2013]. W XXI wieku polskie prace badawcze dotyczące reprezentacji społecznych $\mathrm{w}$ świecie filmu (nurt III na rysunku 1) wpisują się w szersze pole badań nad kulturą popularną [Kurz 2005] czy telewizją z perspektywy socjologii codzienności [Bogunia-Borowska 2012]. Najczęściej ma to miejsce w odniesieniu do seriali telewizyjnych [ [aciak 2013; por. Kurz 2008: 281-302]. Podejmowane są także badania nad praktykami odbiorczymi widzów seriali [np. Halawa 2006; Sokołowski 2011] mieszczące się w ramach socjologii, antropologii, etnografii mediów.

Wedle Żygulskiego socjolog może badać dzieło filmowe z dwóch perspektyw: 1) jako autonomiczną analizę rzeczywistości filmowej zawartą w fabularnej warstwie dzieła; 2) jako analizę zależności zachodzących między rzeczywistością społeczną a fikcyjną rzeczywistością filmową [Żygulski 1966: 49]. Ukierunkowane w ten sposób badanie wymaga wewnętrznego, analitycznego spojrzenia na film. Stanowiło to spore wyzwanie nie tylko dla polskich socjologów. Jak już wspomniano, zagraniczne studia nad reprezentacjami rzeczywistości w świecie filmu również nie należały do popularnych (nurt III na rysunku 1). Pogląd, że kino to narzędzie tłumaczenia rzeczywistości reprezentował w latach 70. francuski socjolog Pierre Sorlin. Wówczas jego postulaty z Socjologii Kina (1977) nie spotkały się z szerszym zainteresowaniem socjologów na gruncie empirycznym. Późniejsze studia Sorlina nad filmem skupiały się na tzw. visible society [Sorlin 1991; por. Sklar, Musser 1990; Murphy 1989]. W Polsce w XX wieku artykulacje w tym nurcie w odniesieniu do badań przeszłości „widzialnego społeczeństwa” 
zaobserwować można w studiach historyków filmu i wizualności [Skotarczak 2004]. Wedle Sorlina kino pozwala nam dostrzec, co społeczeństwo ujawnia jako widzialne w danym momencie jego historii. Rolą badacza jest seryjna analiza utworów kinematograficznych uwzględniająca zaobserwowane zjawiska. Dorota Skotarczak w książce Obraz społeczeństwa PRL w komedii filmowej zajęła się historią PRL-u postrzeganą przez kinowe obrazy z lat 1945-1989. Autorka przeprowadziła analizę wizualno-historyczną filmów, traktując komedie jako filmowe źródła wiedzy o społeczeństwie, oraz opracowała analizę porównawczą (źródła filmowe a inne źródła historyczne), dokonując zestawienia świadectw krytyki (teksty recenzji) i korzystając $\mathrm{z}$ archiwów KC PZPR (materiałów z kolaudacji, stenogramów z zebrań i dyskusji).

Kazimierz Żygulski uważał, że socjologia filmu powinna penetrować pole organizacji produkcji i rozpowszechniania filmów, a także analizować rolę instytucji filmowych w społeczeństwie, ich działania i warunki rozwoju. Ówcześni socjologowie filmu i kina w kraju nie podejmowali tych zagadnień. Po latach próbę syntetycznego opisu warunków rozwoju polskiej kinematografii w odniesieniu do okresu 1945-1981 podjął Kazimierz Michalewicz w swojej książce Film i socjologia, poświęcając jednak zagadnieniu zaledwie czterostronicowy szkic pt. Kinematografia. Rzut systemowy [Michalewicz 2003: 146-150]. Natomiast w okresie żywotności programu Żygulskiego w Polsce historię produkcji i dystrybucji filmów analizował Dieter Prokop [Prokop 1970]. Z perspektywy funkcjonowania systemów polityczno-kapitałowych niemiecki badacz wyróżnił: Polypol, Oligopol, Monopol ${ }^{5}$.

W ostatniej dekadzie w Polsce ukazały się studia poświęcone produkcji i dystrybucji kinowej pisane z perspektywy ekonomiki kultury [Adamczak $2010^{6}$; Wróblewska 2014], czy dotyczące historii gospodarki kinematograficznej [Zajiček 2015]. W 2017 roku interdyscyplinarny zespół naukowy opracował diagnozę pt. Festiwale filmowe w Polsce [2017]. Publikacja stanowi owoc pierwszej inicjatywy badawczej w kraju zorientowanej na opis funkcjonowania współczesnego rynku festiwali czy instytucjonalnych instancji w świecie filmu. Społeczny obieg

5 Pierwsza faza, „Polypol”, trwała od 1895 do 1909 roku. Charakterystyczne dla tego okresu są następujące zdarzenia: wynalezienie i rozwój technologii filmowej oraz wystąpienie zróżnicowanej rywalizacji wynalazców, techników i pierwszych przedsiębiorców kinowych. W okresie od 1909 do 1929 roku miała miejsce bankowa i wielkoprzemysłowa inwestycja w sektorze instytucjonalnym kinematografii, co Prokop nazywa „Oligopolem”. W latach 1930-1946 roku trwał „Monopol”, okres dominacji USA (Hollywood) na rynku światowym, a w kolejnym okresie (do 1970 roku) uwidocznił się międzynarodowy monopol.

6 Polski rynek filmowy nie został przez niego omówiony [por. Adamczak 2010]. 
filmu, warunki rozpowszechniania filmów to temat, który zasługuje na obszerną monografię socjologiczną. Dlaczego socjologowie bardzo rzadko [Ethis 2007] podejmują się realizacji tak ukierunkowanych badań (programowo osadzonych w subdyscyplinie socjologii filmu i kina)? Na potrzeby tego tekstu skierujmy spojrzenie w tę stronę, próbując uchwycić obiektywne trudności.

\section{INSTYTUCJE FILMOWE - MIĘDZY POSTULATEM A PRAKTYKĄ BADAŃ}

Niezależnie od tego, czy traktujemy kino jako rozrywkę, czy sztukę filmową, produkcja i konsumpcja odbywa się za pośrednictwem instytucji. W każdym polu sztuki dostrzec można liczne podziały (m.in. na sztukę elitarną, kanon światowy, kanon narodowy, sztukę masowa, popularna, prawomocną, nieprawomocna, awangardę, kicz). Porządek społeczny i artystyczny w tym świecie narzucają instytucje sakralizacji [Bourdieu 2001]. O jakich instytucjach i instancjach w świecie kinematografii mówimy? Śledząc pokrótce drogę procesu instytucjonalnego kina w świecie sztuki, zauważmy, że pole to podlegało zarówno tendencji do autonomizacji, jak i uprzemysłowienia, urynkowienia. W polu przemysłu kinowego i produkcji kulturalno-artystycznej możemy dostrzec podobieństwo struktury. Od początku rozwoju kina na świecie ujawniły się silne ośrodki dominacji, kontroli filmu i władzy. $Z$ różnym natężeniem w poszczególnych krajach działały odpowiedniki takich instancji, jak: cenzura, stowarzyszenia twórców, krytyka, festiwale i instytuty oraz państwowe szkoły. Jako ostatnie pod względem chronologicznym zaistniały filmowe organizacje międzynarodowe.

$\mathrm{W}$ procesie instytucjonalizacji kina jako wynalazku, rozrywki i sztuki przestrzenią materialnego funkcjonowania były namioty, budy, kinoteatry, cyrki, kinematografy ruchome i objazdowe, a potem kina stałe. Studia filmowe i wytwórnie powstawały najwcześniej we Francji (Pathe, Gaumont). Francuzi rozwijali również oddziały zagraniczne. Dekadę później wytwórnie i studia filmowe pojawiły się w Stanach Zjednoczonych (np. Motion Picture Patents Company 1908; Nestor 1911). Tworzyli je sami twórcy - producenci kina, o czym świadczy przykład United Artist (1919). Gdy budowano stacjonarne studia w polu kinematografii, szybko uaktywniła się cenzura. Już w 1909 roku w Nowym Jorku powołano organizację cenzorską New York Board of Motion Picture Censorship, później znaną jako National Board Review (NBR). Ponad dwie dekady później w USA spisano słynny kodeks Haysa, obowiązujący przez kilkadziesiąt lat. Cenzura w stosunku do mediów masowych funkcjonowała we wszystkich krajach, choć w różnym zakresie odnośnie do kwestii obyczajowych, 
społecznych czy politycznych (np. w Hiszpanii, w Rosji czy w Polsce silniejsza była cenzura polityczna niż społeczna).

Stosunkowo wcześnie, bo już od 1926 roku, w Paryżu działała Międzynarodowa Konfederacja Związków Autorów i Kompozytorów (CISAC). Nie cechowała ją taka synergia kapitałów (ekonomicznego, symbolicznego, społecznego) jak Amerykańską Akademię Sztuki i Wiedzy Filmowej utworzoną przez Louisa B. Mayera w 1927 roku. Dwa lata później (w 1929 roku) jej członkowie po raz pierwszy przyznali nagrodę zwaną popularnie Oscarem, co w toku historii przyczyniło się do coraz wyższej pozycji Amerykańskiej Akademii w polu kinematografii. Potentat filmowy Mayer (Metro-Goldwyn-Mayer) chciał zapobiec rozprzestrzenianiu się związków zawodowych w hollywoodzkich wytwórniach. Potrzeba kontroli rynku sprawiła, iż ,wielki gracz” w polu kinematografii postanowił zrzeszyć pracowników takich jak: reżyserzy, aktorzy, technicy, producenci, pisarze, technicy. Spośród „członków założycielskich” tej organizacji największą grupę stanowili producenci (12 osób), zaś członkami nadzwyczajnymi stali się adwokaci odpowiadający za statut Akademii [Krakowski 2012: 22]. Po upływie trzech miesięcy do zrzeszenia zapisało się ponad 230 osób. Dziś tę liczbę szacuje się na 6000 członków skupionych w 15 oddziałach. Większość z nich to biali mężczyźni powyżej 50 lat. Wedle wyliczeń „The Los Angeles Times” ich średnia wieku w 2012 roku wynosiła 62 lata [por. Krakowski 2012: 27]. Pierwotnie wstępnym warunkiem kwalifikacji filmu do „oscarowej” nominacji był fakt wyświetlania go w kinie w Los Angeles. Obecnie minimalny czas emisji kinowej to siedem dni, przynajmniej dwa seanse dziennie w wielkim komercyjnym kinie w Los Angeles, poświadczona sprzedaż biletów, reklama w prasie, specjalne eventy. Początkowo wydarzenie nie posiadało wysokiego kapitału społecznego (dużego oddźwięku społecznego). Rozmach i splendor objawił się w późniejszym okresie. O pierwszych galach media informowały szeroko, bowiem przeszły już tzw. pierwszy próg umasowienia po I wojnie światowej. Ruch założycielski Mayera był ważny nie tylko z perspektywy historycznej. Świadczył o obudowanej instytucjonalnie hegemonii w polu kina - przemysłu, a także o dominacji kapitału ekonomicznego. Niekwestionowana, liderska pozycja Amerykańskiej Akademii Filmowej w historii jest istotna, gdyż Europejską Akademię Filmową utworzono dopiero w 1988 roku.

Inaczej kształtują się losy powołania tzw. instytutów filmowych, a więc organizacji niedochodowych wspierających produkcję filmowa, edukację, narodowe dziedzictwo, sztukę kinematografii. Daty powstania są pewnymi wskaźnikami kapitału państwowego i polityki kulturalnej państw w dziedzinie filmu, np. Bry- 
tyjski Instytut Filmowy (1933), Niemiecki Instytut Filmowy (1949), Szwedzki Instytut Filmowy (1963), Amerykański Instytut Filmowy (1967).

Z kolei rola krytyków w polu instytucjonalnym kina - sztuki zaznaczyła się stosunkowo wcześnie, najpierw w polu oficjalnej cenzury, prasy, radia, a wreszcie w ramach stowarzyszeń i organizacji. Międzynarodowa Federacja Krytyków Filmowych (FIPRESCI) rozpoczęła działalność w 1930 roku w Brukseli. Warto podkreślić, że w pierwszej dekadzie społecznego funkcjonowania kina (zarówno jako rozrywki, jak i sztuki) nie było festiwali. Ta instancja instytucjonalna pojawiła się znacznie później. Najstarszy filmowy festiwal na świecie odbywa się w Wenecji. Jego pierwsza edycja miała miejsce w 1932 roku, po blisko 36 latach od płatnego pokazu filmowego braci Lumière. Inne ważne, stałe festiwale organizowano dopiero po drugiej wojnie światowej, np. w Locarno (1946), w Karlovych Warach (1946), w Avignion (1947), w Edynburgu (1947), w Berlinie (1951), w Cannes (1946), w Moskwie ${ }^{7}$ (1959), w San Sebastian (1953), w Melbourne (1951), w Goa (1952), w Menheim i w Heidelbergu (1952), w Mar del Plata (1954). Z tej perspektywy ważną dekadą pozostawały lata 70. XX wieku. Wówczas zaistniały międzynarodowe festiwale w Sundance (1978), w Montrealu (1977), w Roterdamie (1972). Festiwale powstawały także w Polsce. Najdłuższą tradycję w kraju posiada Krakowski Festiwal Filmowy skupiający się na przeglądzie dokumentów, który jest jednocześnie jednym z najstarszych w Europie festiwalem kina dokumentalnego. Pierwsza edycja tego wydarzenia miała miejsce w 1961 roku pod nazwą Ogólnopolski Festiwal Filmów Krótkometrażowych. Z kolei w 1973 roku zorganizowano Koszaliński Festiwal Debiutów Filmowych „Młodzi i Film”, a rok później Festiwal Polskich Filmów Fabularnych (obecnie Festiwal Filmowy Gdynia). W XXI wieku powstają nowe, ważne, międzynarodowe inicjatywy festiwalowe czy konkursowe, np. Festiwal Filmowy w Rzymie (2005), w Bratysławie (2000), w Polsce - Nowe Horyzonty (2001), i wiele innych. Jest to pole badań socjologów kina. Współcześnie charakteryzuje się raczej słabą aktywnością badaczy, choć zdarzają się wyjątki, o czym świadczy przykład francuskiej socjologii kina. Emmanuel Ethis od dekady poświęca swoje studia instytucjom kina, w tym festiwalowej publiczności w Awinionie [zob. Ethis 2007]. Jak już wspomniano wcześniej, polskie, współczesne festiwale filmowe doczekały się zbiorowego opracowania - diagnozy ich funkcjonowania na rynku ekonomiczno-kulturowym polskich wydarzeń filmowych [Drzał-Sierocka i in. 2017].

Państwowe szkoły filmowe, akademie kształcące filmowców powstawały w różnym okresie. Najwcześniej powołano Wszechrosyjski Państwowy Uniwer-

\footnotetext{
7 Pierwsza edycja miała miejsce w 1935 r. W następnych latach wydarzenie nie odbywało się.
} 
sytet Kinematografii im. S.A. Gierasimowa (1919) w Moskwie. Dekadę później szkołę dla filmowców założono w Ameryce przy Uniwersytecie w Kalifornii za sprawą Amerykańskiej Akademii Filmowej (1929). Z kolei najstarszą uczelnią w Europie Zachodniej jest włoska szkoła Centro Sperimentale di Cinematografia działająca w Rzymie (od 1935). Paryski Institut des hautes études cinématographiques (IDHEC) utworzono w 1943 roku. Szkoły filmowe w Czechach (1946) i w Polsce (1948) powołano po drugiej wojnie światowej; podobnie jak w Bułgarii (1948). Proces instytucjonalizacji szkolnictwa w dziedzinie kinematografii rozprzestrzeniał się w kolejnych dekadach. W latach 50. XX wieku utworzono szkołę filmową w Londynie, a w latach 60. na przykład w Indiach, w Szwecji, w Monachium; kolejne szkoły powoływano w następnych dziesięcioleciach. Wciąż rozwija się na świecie prywatne szkolnictwo w dziedzinie kinematografii. Szkoły i festiwale zajmują różne układy pozycji i władzy symbolicznej w polu instytucji kultury i sztuki filmowej. Liczba festiwali, konkursów i przeglądów filmowych na świecie stale się powiększa. Świadczy to o rozwoju filmowych instancji sakralizujących dzieła i twórców. Jednak najsilniejszą pozycję w polu kinematografii posiadają najstarsi gracze, aktorzy instytucjonalni (długa tradycja działania w polu światowej lub rodzimej kinematografii) o największym kapitale (ekonomicznym, kulturowym, społecznym, symbolicznym) - Amerykańska Akademia Filmowa i Europejska Akademia Filmowa.

Dopiero od 1980 roku swoją organizację posiadają europejscy reżyserzy i twórcy dzieł audiowizualnych. Chodzi mianowicie o Federację Reżyserów Filmów Europejskich (FERA) czy Stowarzyszenie Międzynarodowego Kolektywnego Zarządzania Dziełami Audiowizualnymi AGICOA (1981).

W każdym kraju geneza, sieć, struktura, układy, zależności, wzajemne powiązania w polu kultury filmowej, a także interesy i konflikty kształtowały się w długim procesie w ciągu całego XX wieku. W XXI wieku wciąż w tym obszarze zachodzą przesunięcia, ale ich opisanie, zbadanie reguł rynku sztuki filmowej, za Bourdieu [Bourdieu 2001], wydaje się niewykonalne. Po pierwsze, nowe instancje instytucjonalne charakteryzuje ten sam brak transparentności w działalności na szerokim rynku kinematograficznym. Po drugie, po latach materiał badawczy stanowią źródła zastane (np. opublikowane wspomnienia, dokumenty osobiste). Po trzecie, rynek sztuki filmowej działa w sposób niejawny (władza symboliczna, przemoc symboliczna). Socjolog może uzyskać informacje na temat społeczno-artystycznej obsady gremiów, ale nie na temat ich rekrutacji. W Polsce PISF posiada stronę internetową, jednak udostępnione dane nie dotyczą doboru gremiów, uzasadnień różnorodnych werdyktów, informacji o odbytych obradach 
konkursowych, struktury komisji przyznających dotacje filmowe. W 2016 roku Stowarzyszenie Kobiet Filmowców Polskich zwróciło się z prośbą do PISF o udostępnienie danych o proporcjach płci w składach komisji oceniających projekty filmowe. PISF odmówił udostępnienia statystyk, thumacząc opracowanie takich zestawień dużą czasochłonnością. Niejawność informacji na ten temat pozostaje regułą w polu - standardem światowym. Dotyczy to także konkursów i festiwali. Przeprowadzone analizy własne na użytek niniejszego tekstu wskazują że informacje o kryteriach ocen nie są dostępne szerokiej publiczności. Na zewnątrz pola werdykty uzasadniane są „magią sztuki”. Każde dzieło posiada treść, formę i ekspresję, ale na ogół widzom nie wyjaśnia się, dlaczego dany film jest „wielki”. Natomiast jurorzy jako profesjonaliści posiadają wiedzę „tajemną", niedyskursywną i nieużywaną explicite. Amerykańska Akademia Filmowa po kłótni z założycielem Mayerem o werdykt 15 lutego 1929 roku uchwaliła, iż członków komisji obowiązuje tajemnica aż do ogłoszenia werdyktu na scenie w trakcie gali wręczania nagród. Ogólnie łatwo dostrzec, że wszystkie werdykty festiwalowe komisji cechuje lapidarność. Toteż opinie nie mogę być kontestowane przez zwykłego widza. Jednakże publiczność festiwali filmowych to kompetentni odbiorcy, którzy wypracowali metodę na „okaleczone werdykty”, wymuszając nagrody publiczności. Rozdźwięk pomiędzy nagrodą publiczności i nagrodą jurorów stanowi interesujący przyczynek do analiz. Jednostka posiadająca kapitał kulturowy przekazuje ten rodzaj kapitału na kapitał społeczny lub ekonomiczny, a uzasadnienie nagrody odbywa się wedle linii artystycznej. W ten sposób w polu sztuki mamy do czynienia z prawem konwersji kapitału [Bourdieu 2005]. Pierre Bourdieu był przekonany, że działa tu habitus klasowy lub sojusz klasowy, przejawiający się w tym, iż w polu liczą się ludzie podobni społecznie. Ma to miejsce, gdy w grę wchodzą tzw. wysokie stawki (prestiż i finanse). Sama nagroda w środowisku filmowym to konglomerat kapitałów (symbolicznego, kulturowego i ekonomicznego), swoista „kapitalizacja kapitałów”.

Spoglądając na największe instytucje $\mathrm{w}$ polu rodzimej kinematografii w XXI wieku, bez trudu można zauważyć, że decydująca rolę w kwestii finansowania produkcji posiada Polski Instytut Sztuki Filmowej, działający w kraju od 2005 roku, podlegający Ministerstwu Kultury i Dziedzictwa Narodowego. Bez kapitału państwowego (publiczne fundusze ministerialne, samorządowe, wojewódzkie, lokalne) trudno w Polsce realizować cykliczne wydarzenie filmowe. Potwierdza to raport Festiwale filmowe w Polsce [Drzal-Sierocka $\mathrm{i}$ in. 2017: 16-27], w którym grupa kulturoznawców i socjologów zbadała dwanaście festiwali wytypowanych z listy dziewięćdziesięciu wydarzeń opracowanych przez PISF (tzw. mapa festiwali). Autorzy, posługując się różnymi technikami badań 
jakościowych i ilościowych, opisali festiwalową perspektywę widzów, organizatorów, lokalnej społeczności, ale także władz samorządowych i sponsorów [Drzał-Sierocka i in. 2017: 66-69]. Analizie poddano także zasady finasowania festiwali filmowych, obecność sponsorów tytularnych lub strategicznych-choć nie we wszystkich przypadkach udało się to ustalić (np. Międzynarodowy Festiwal Sztuki Zdjęć Filmowych Camerimage, Przegląd Filmowy Kino na Granicy, Warszawski Międzynarodowy Festiwal Filmowy) [Drzał-Sierocka i in. 2017: 184, 188, 190]. Pomijanie w niniejszej części artykułu pozycji producentów prywatnych i sponsorów w Polsce nie ma na celu deprecjonowania ich roli. Autorka pragnie jedynie podkreślić, że choćby tak ,podstawowe dane” (nawet jeśli badacz pyta o nie w ankietach, wywiadach) nie zawsze są udostępniane, zaś wchodzenie przez socjologów na utajnioną, zakazaną stronę pola może spotkać się z agresją. O różnorodnych trudnościach związanych ze zbieraniem ilościowych danych pisze Anna Wróblewska [2013]. W dyskursie publicznym obserwujemy ukrywanie danych o kapitale ekonomicznym oraz eksponowanie konfliktów. Nieporozumienie na linii władza (MKiDN) - instytut (PISF) odzwierciedlają na przykład następujące zdarzenia: konflikt z powodu filmu Ida (2013) pomiędzy Agnieszką Odorowicz (PISF) a obozem władzy, protest polskich reżyserów w sprawie komentarza w TVP2 przed emisją filmu Ida czy dymisja dyrektor PISF Magdaleny Sroki nagłośniona medialnie w październiku 2017 roku$^{8}$. Jednym ze wskaźników krajowych napięć w kinematografii jest dywersyfikacja w polu stowarzyszeń twórców. Stowarzyszenie Filmowców Polskich powstało w 1966 roku i jest liderem organizacji filmowych w Europie Środkowo-Wschodniej; członkiem najważniejszych światowych organizacji audiowizualnych, takich jak: FERA, AIDAA, CISAC, AGICOA, FIPRESCI oraz CIFEJ. Stowarzyszenie Filmowców Polskich skupia osoby pracujące w zawodzie filmowym, np. odpowiedzialne za reżyserię, scenariusze, krytykę filmową, animację, zdjęcia itp. W 2014 roku w opozycji do SFP wyłoniła się inicjatywa środowiska kobiet - Stowarzyszenie Kobiet Filmowców Polskich. Twórczynie w reakcji na męską hegemonię utworzyły własny odłam stowarzyszeniowy. Ich aktywność skupia się na celach edukacyjnych, a także wspieraniu kobiet w branży filmowej, propagowaniu wiedzy o żeńskiej twórczości filmowej, zazwyczaj pomijanej w encyklopediach. Instytucjonalny zwrot $\mathrm{w}$ środowisku rodzimych filmowców zauważyć można także dzięki utworzeniu Gildii Reżyserów Polskich w 2016 roku. W składzie za-

8 Szerzej: https://wiadomosci.wp.pl/protest-polskich-rezyserow-ws-komentarzaprzed-filmem-ida-w-tvp2-krzysztof-klopotowski-odpowiada-na-zarzuty-wymowa-filmu-jestniekorzystna-dla-polski-6025263394432129a; https://www.newsweek.pl/kultura/magdalena-srokaodwolana-przez-glinskiego-z-funkcji-szefa-pisf/3w2w5hp. 
rządu pod względem płci dominują kobiety (6 kobiet, 3 mężczyzn). Natomiast na około 56 członków przypada 12 członkiń. Dyrektorem jest producentka filmowa Magdalena Lankosz [Zob. http://polishdirectors.com/o-nas/]. Gildia pozostaje najmłodszą organizacją twórców i twórczyń, ale nie najsłabszą w polu rodzimej kinematografii. Na jej kapitał symboliczny, społeczny i kulturowy składają się między innymi autorytet $\mathrm{w}$ polu, dokonania i osobowości uznanych twórców. Przewodniczącą Gildii jest Joanna Kos-Krauze. W skład zarządu wchodzą także reżyserki: Agnieszka Holland i jej córka Katarzyna Adamik, Anna Kazejak oraz dokumentalistka Maria Zmarz-Koczanowicz. Związek zawodowy Gildia Reżyserów Polskich przyznaje od 2016 roku swoją nagrodę (za nonkonformizm) krajowym twórcom filmowym (Nagroda im. Krzysztofa Krauze), co można czytać w kontekście próby wzmocnienia (pomnożenia) symbolicznego kapitału i walki w polu kinematografii o autonomię. Dotychczas w trakcie dwóch edycji nagrodzono Grzegorza Królikiewicza za film Sasiady (2016) oraz Wojciecha Smarzowskiego za Wotyń (2017).

\section{PODSUMOWANIE}

Celem artykułu była refleksja na temat praktyk w polu socjologii kina i filmu. Wymagało to przeglądu najważniejszych prac socjologicznych, wyodrębnienia podziałów i nurtów, wskazania programów, postulatów, także takich, które nie zostały zrealizowane. W analizowanym tu polu nauki, jakim jest socjologia filmu i kina, decydujące znaczenie mają historycznie ukonstytuowane i zinstytucjonalizowane nurty badawcze, prądy, tendencje metodologiczne. Osobną kwestia, niebraną tu szerzej po uwagę, pozostaje wpływ pola społecznego na pole nauki. O roli historii i polityki w kształtowaniu pola naukowego świadczy droga socjologii filmu i kina do zdobycia pozycji pełnoprawnej subdyscypliny w Polsce.

Społeczną rolę filmu akcentowali pionierzy myśli filmowej, wynalazcy, pedagodzy, psychologowie, a dopiero później socjologowie filmu. Od początku rozwoju kina jako medium wśród krytyków na świecie i w Polsce, w tym rodzimych pedagogów (np. Skoczylas), psychologów (np. Blaustein), socjologów, upowszechniała się opinia, że filmy bardzo oddziałują na odbiorców, ale przyczyn tego fenomenu nie dociekano. Późniejsi badacze zjawiska wpływu kina czy telewizji na widzów podkreślali, że niezmiernie ważne dla jednostki pozostaje wypracowanie nawyku i obyczaj odbierania treści filmowych. Dostrzegano nie tylko zagrożenie płynące z filmów, ale i ich wielki potencjał edukacyjny, wychowawczy (edukacja poprzez film). 
Podsumowując polskie zainteresowania i badania w polu socjologii filmu i kina, trzeba stwierdzić, że mieszczą się one w dwóch głównych nurtach empiryczno-teoretycznych, jednak pojawiły się z dużym opóźnieniem w stosunku do krajów zachodnich, co w dużej mierze związane jest z historią państwa. Ogólnie polska socjologia filmu rozwijała się niejednorodnie, w długim okresie po drugiej wojnie światowej i pod wpływem różnych nauk o filmie i kulturze [Wejbert-Wąsiewicz 2017: 17-46]. Z nakreślonych tu uwag o charakterze historycznym wyłania się słaba pozycja polskiej socjologii kina i filmu w tym polu naukowym. Efemeryzm krajowych programów, postulatów oraz brak kontynuatorów wedle badań Bystronia, Salzmana, Żygulskiego potwierdza siłę dziedzictwa instytucjonalnego wymiaru nauki (habitusu dyscyplinarnego - mówiąc za Bourdieu). Okazjonalność niektórych przedsięwzięć wynikała także z braku kapitału ekonomicznego w polu socjologii kina i filmu (niedostatek, słabe finansowanie tych projektów). Obserwujemy także przemieszczanie się pewnych pól zainteresowań badawczych poza opisywaną tu subdyscyplinę, np. badania widowni filmowej to pole badań pedagogów, socjologów, a współcześnie kulturoznawców i filmoznawców [por. Klejsa 2014]. W ostatniej dekadzie w Polsce socjologiczna refleksja nad dziełem filmowym i obrazem filmowym wpisuje się w szerszą problematykę kultury wizualnej i audiowizualnej [por. Filiciak 2013; Drzał-Sierocka, Godzic 2010], co wiąże się ze zwrotem ikonicznym w polu nauki. Zastosowanie filmu w socjologii i dla socjologii, w tym filmu socjologicznego, opisał Jerzy Kaczmarek [Kaczmarek 2014], który posiada duże zasługi w dydaktyce w zakresie filmu socjologicznego (Pracownia Socjologii Wizualnej UAM w Poznaniu). Obecnie klasyczna socjologia filmu jako fakultatywny kurs zajęć dla studentów socjologii proponowana jest na Uniwersytecie Jagiellońskim, Warszawskim i Łódzkim 9 . Za granicą popularność zyskują kursy z socjologii bazujące na analizie filmów - Sociology through film [Sutherland, Feltey 2009]. Na koniec można zapytać: czy istnieje nowy program socjologii filmu? Prawdopodobnie w dobie nowych mediów, interaktywności kina wciąż żywotne pozostaje stare pytanie: co ludzie robią z filmami, i dlaczego? Wydaje się, że choć zmieniły się warunki odbioru filmów i kina, stare nurty badawcze subdyscypliny są nadal aktualne (choć niektóre zostały już być może na zawsze porzucone). Największe zaniedbania $\mathrm{w}$ polu socjologii filmu widać $\mathrm{w}$ zakresie jej powiązań $\mathrm{z}$ socjologią sztuki. Ponadto w Polsce socjologowie filmu, w porównaniu z zagranicznymi

9 Informacje na podstawie sylabusów uczelni dostępnych w sieci z dn. 31.10.2018. Wykłady lub konwersatoria oferowane są w ramach specjalizacji (kultura, sztuka, kultura masowa). Specjalizacje socjologiczne związane z komunikacją i mediami oferują zajęcia z socjologii, antropologii mediów (wiedza o filmie i kinie jest zdominowana przez treści o gatunkach telewizyjnych). 
reprezentantami tej subdyscypliny [por. Jarvi 1970; Prokop 1970; Żygulski 1966; Darmas 2014], nie zajmowali się analizą organizacji produkcji i rozpowszechniania filmów, a także badaniem roli instytucji filmowych w społeczeństwie, ich działaniem i warunkami rozwoju. Ten kierunek stanowi dopiero od niedawna obszar eksploracji dla polskich filmoznawców, historyków kina [Adamczak 2010, Zajiček 2015]. Choć naukowo opisano dzieła i artystów, prądy, nurty, badania publiczności, opis funkcjonowania wyszczególnionych instytucji w tym polu stanowi wciąż niezrealizowane zadanie. Dzieje się tak, gdyż informacje pozostają rozproszone, indywidualne, niesystematyczne, prywatne i nie posiadamy do nich dostępu na bieżąco. Dla socjologa „zasada braku danych” jest istotną informacją. Utajniona kultura ujawnia się szczątkowo i sprawozdawczo po wielu dekadach dzięki żmudnym pracom historyków filmu w archiwach, jeśli takie istnieją [por. Szczutkowska 2014]. Pole nauki o filmie pozostaje bardziej jawne niż pole sztuki filmu, pole kinematografii.

\section{BIBLIOGRAFIA}

Adamczak Marcin. 2010. Globalne Hollywood, filmowa Europa i polskie kino po 1989 roku. Gdańsk: wyd. słowo/obraz terytoria.

Balazs Bela. 1987. Wybór pism. Warszawa: Wydawnictwa Artystyczne i Filmowe.

Bevans George E. 1913. How working men spend their spare time. New York, New York USA: Columbia University Press.

Blumer Herbert. 1933. Movies and conduct. New York: The Macmillan Company.

Blumer Herbert. 1933. Movies, delinquency, and crime. New York: The Macmillan Company.

Bocheńska Jadwiga. 1975. Antologia tekstów o kinie, powstatych na przestrzeni lat 1898-1939. Wrocław: Ossolineum.

Bogunia-Borowska Malgorzata. 2012. Fenomen telewizji. Interpretacje socjologiczne i kulturowe. Kraków: Wydawnictwo Uniwersytetu Jagiellońskiego.

Bourdieu Pierre. 2009. Rozum praktyczny. Kraków: Wyd UJ.

Bourdieu Pierre. 2001. Reguty sztuki. Kraków: Universitas.

Bourdieu Pierre. 2005. Dystynkcja. Społeczna krytyka władzy sądzenia. Warszawa: Wydawnictwo naukowe Scholar.

Bourdieu Pierre. 2008. Zmyst praktyczny. Kraków: Wyd UJ.

Bourdieu Pierre. 2013. „Homo Academicus. Posłowie dwadzieścia lat później”. Praktyka Teoretyczna 2: 31-50. http://www.praktykateoretyczna.pl/PT_nr7_2013_NOU/03. Bourdieu.pdf.

Box Kathleen, Loiss Moss. 1943. The cinema audience. London: Central Office of Information.

Bystroń Jan. 1919. „Socjologia kina”. Ekran 11: 1.

Dale Edgar. 1933. The content of motion pictures. New York: Macmillan.

Darmas Marcin. 2014. Obywatel Rycerz. Zarys socjologii filmu. Warszawa: Wyd. UW.

Drozdowski Rafal, Marek Krajewski. (red.). 2010. Za fotografię! W stronę radykalnego programu socjologii wizualnej. Warszawa: Wyd. Fundacja Nowej Kultury Bęc Zmiana. 
Drzal-Sierocka Aleksandra, Elżbieta Durys, Mirosław Filiciak, Piotr Majewski, Anna Pietraszko, Michał Rauszer, Radosław Sierocki, Anna Szczeblewska, Karol Wittels. 2017. Festiwale filmowe $w$ Polsce. Raport 2017. http: //www.obserwatorium.org.pl/wp-content/ uploads/2018/02/Festiwale_filmowe_PL-Raport.pdf.

Drzal-Sierocka Aleksandra, Wiesław Godzic. (red.). 2010. Media audiowizualne. Podręcznik akademicki. Warszawa: Wyd. Akademickie i Profesjonalne.

Esquenazi Jean-Pierre. 2007. Sociologie des oeuvres. De la production ŕ l'interprétation. Paris: Armand Colin.

Ethis Emmanuel. 2007. Sociologie du cinéma et de ses publics. Paris: Armand Colin.

Ferro Marc. 2011. Kino i historia. Warszawa: PWN.

Filiciak Mirosław. 2013. Med ia, wersja beta: film i telewizja w czasach gier komputerowych $i$ internetu. Gdańsk: Wydawnictwo Naukowe Katedra.

Fiske John. 2010. Zrozumieć kulture popularną. Kraków: Wyd. UJ.

Gałuszka Mieczysław, Kazimierz Kowalewicz. 1977. „Szkic do badań potocznego odbioru filmu". Kino 11: 29-31

Gałuszka Mieczysław. 1984. „Potoczne odtworzenie filmu”. Studia Socjologiczne 4: 161-184.

Gałuszka Mieczysław. 1996. Między przyjemnościa a rytuałem. Serial telewizyjny w kulturze popularnej. Łódź: Wyd. AM.

Gierszewska Barbara. 2005. „Film i kino w lwowskiej prasie 1895-1918”. Studia Bibliologiczne Akademii Świętokrzyskiej 9: 13-33.

Godzic Wiesław. 1996. Oglądanie i inne przyjemności kultury popularnej. Kraków: Universitas.

Halawa Mateusz. 2006. Życie codzienne z telewizorem. Warszawa: Wydawnictwa Akademickie i Profesjonalne.

Hall Stuart. 1979. „Serial albo obłaskawianie świata”. Przekazy i Opinie 2: 58-72.

Hall Stuart. 1987. „Kodowanie i dekodowanie”. Przekazy i Opinie 1-2: 58-71.

Hertz Aleksander. 1938. „Zadania społeczne teatru”. Scena Polska 2-3: 402-425.

Horkheimer Max, Theodor Adorno. 1994. Dialektyka oświecenia. Warszawa: IFiS PAN.

Jacyno Małgorzata. 1998. „Portret bohatera ze stygmą. Bohater seriali telewizyjnych”. Kultura Współczesna 2-3: 36-49.

Jarvie Ian. 1970. Movies and society. New York: Basic Books Inc. Publishers.

Klejsa Konrad. 2014. „Badania widowni filmowej: historia i współczesność (rekonesans bibliograficzny)". Kwartalnik Filmowy 85: 100-117.

Kluszczyński Ryszard. 2008. Doświadczenie - pamięć - tożsamość. Doświadczenie medialne jako fundament hybrydycznej tożsamości W: Nowoczesność jako doświadczenie. Dyscypliny-paradygmaty - dyskursy, A. Zeidler-Janiszewska, R. Nycz (red.), 170-184. Warszawa: Wydawnictwo SWPS „Academica”.

Kłoskowska Antonina, Rokuszewska-Pawełek Alicja. 1977. „Mity literackie w świadomości potocznej: (przykład potocznego odbioru Wesela)". Kultura i Społeczeństwo 1: 35-62.

Kościelski Zygmunt. 1987. „Odbiór i ocena serialu „Ptaki ciernistych krzewów”. Aktualności Radiowo-Telewizyjne 5: 12-20.

Kowalewicz Kazimierz. 1978. „Notatki do szkicu o odbiorze filmów na przykładzie Prześwietlenia Krzysztofa Kieślowskiego". Przekazy i Opinie 4: 11-22 .

Kracauer Siegfried. 2009. Od Caligariego do Hitlera: z psychologii filmu niemieckiego. Gdańsk: słowo/obraz terytoria.

Krakowski Andrzej. 2013. „Jak Oscar stał się Oscarem”. Film 2: 22-27. 
Kurz Iwona (red.). 2008. Film i historia: antologia. Warszawa: Wydawnictwa Uniwersytetu Warszawskiego.

Kurz Iwona. 2005. Twarze w thumie. Wizerunki bohaterów wyobraźni zbiorowej w kulturze polskiej lat 1955-1969. Warszawa: Świat Literacki.

Latour Bruno. 2010. Splatając to co nowoczesne. Wprowadzenie do teorii aktora-sieci. Kraków: Universitas.

Lazarsfeld Paul. 1947. "Audience research in the movie field". The Annals of American Academy of Political and Social Science 254(1): 160-168. doi: 10.1177/000271624725400125.

Lewicki Bolesław. 1935. Młodzież przed ekranem. Lwów: Drukarnia „Słowa Polskiego”.

Laciak Beata. 2013. Kwestie spoleczne w polskich serialach obyczajowych-prezentacje i odbiór. Analiza socjologiczna. Warszawa: Wydawnictwo Akademickie Żak.

Manvell Roger. 1946. Survey of the cinema and its public. London: Pelican Book.

Mayer Jacob. 1946. Sociology of film: Studies and documents. London: Dennis Dobson.

Mayer Jacob. 1948. British cinemas and their audiences: Sociological studies. London: Dennis Dobson.

Michalewicz Kazimierz. 1998. Polskie rodowody filmu. Narodziny masowego zjawiska. Warszawa: Polska Agencja Ekologiczna SA.

Michalewicz Kazimierz. 2003. Film i socjologia. Warszawa: Neriton

Morawski Stefan. 1977. Kultura filmowa młodzieży. Warszawa: Wydawnictwo COK.

Morin Edgar. 1975. Kino i wyobraźnia. Warszawa: PIW.

Murphy Robert. 1989. Realism and tinsel: Cinema and society in Britain 1939-48. London: Routledge.

Olechnicki Krzysztof. 2009. Fotoblogi, pamiętniki z opcja przekazu. Fotografia i fotoblogerzy w kulturze konsumpcyjnej. Warszawa: WAIP.

Ossowski Stanisław. 1958. U podstaw estetyki. Warszawa: PWN.

Peters Charles. 1933. Motion pictures and standards of morality. New York: Macmillan Company.

Piekarski Ireneusz. 2007. „Stanisław Salzman - gawęda tragiczna. Lwowski esej środowiskowy". Teksty Drugie 5(107): 214-225.

Prasek Cezary. 1970. „Czym mogłaby być socjologia filmu?”. Kino 56: 30-33.

Prasek Cezary. 2010. Złota młodzież PRL. Warszawa: Bellona.

Prasek Cezary. 2013. Film i jego obraz w PRL. Warszawa: Bellona.

Prokop Dieter. 1970. Soziologie des films. Berlin: Luchterhand.

Renshaw Samuel, Vernon Miller, Dorothy Marquis. 1933. Children's sleep. New York: Arno Press.

Siemieńska Renata. 1981. „Percepcja serialu telewizyjnego a sytuacja osobista oraz stosunek do narodu(na przykładzie Szpitala na peryferiach)”. Przekazy i Opinie 1: 49-54.

Sklar Robert, Charles Musser. 1990. Resisting images. Essays about cinema and history. Philadelphia: Temple University Press.

Skotarczak Dorota. 2004. Obraz społeczeństwa PRL w komedii filmowej. Poznań: Wydawnictwo Naukowe UAM.

Sokołowski Lukasz. 2011. „Serial jako element praktyk społecznych”. Kultura i społeczeństwo 2-3: 187-208.

Sorlin Pierre. 1991. European cinema European societies 1939-1990. New York: Routledge.

Sutherland Jean-Anne, Kathryn M. Feltey. 2009. Cinematic sociology: Social life in film. Los Angeles, London, New Delphi, Singapore, Washington DC: Sage Publications. 
Szczutkowska Joanna. 2014. Polityka kulturalna PRL $w$ dziedzinie kinematografii w latach 70. Bydgoszcz: Wyd UKW.

Sztandar-Sztanderska Karolina. 2010. Teoria praktyki i praktyka teorii. Wstęp do socjologii Pierre'a Bourdieu. Warszawa: WUW.

Tudor Andrew. 1974. Image and influence. Studies in the sociology of film. London: Allen \& Unwin.

Wejbert-Wąsiewicz Ewelina. 2017. Bez retuszu czy po liftingu? Obrazy starości i aborcji w filmie. Łódź: Wyd. UŁ.

Wróblewska Anna. 2013. „Polska produkcja filmowa po roku 2005 w perspektywie badań ilościowych”. Images 22 (13): 9-25.

Wróblewska Anna. 2014. Rynek filmowy w Polsce Warszawa: Wydawnictwo Wojciech Marzec.

Zajiček Edward. 2015. Zarys historii gospodarczej kinematografii polskiej. Tom I. Łódź: Wydawnictwo PWSFTviT.

Žižek Slavoy. 2001. Wzniosły obiekt ideologii. Wrocław: Wydawnictwo Uniwersytetu Wrocławskiego.

Znaniecki Florian. 1934. Ludzie teraźniejsi a cywilizacja przyszłości. Lwów-Warszawa: Książnica-Atlas.

Żygulski Kazimierz. 1966. Socjologia filmu. Kraków: Wyd. Artystyczne i Filmowe.

\section{Źródła internetowe:}

Gildia Reżyserów Polskich. http://polishdirectors.com/o-nas/ [dostęp: 12.09.2018].

Magdalena Sroka odwołana z funkcji dyrektora Polskiego Instytutu Sztuki Filmowej przez ministra Glińskiego. https://www.newsweek.pl/kultura/magdalena-sroka-odwolana-przezglinskiego-z-funkcji-szefa-pisf/3w2w5hp [dostęp: 02.05.2018].

Wiadomości WP. https://wiadomosci.wp.pl/protest-polskich-rezyserow-ws-komentarza-przedfilmem-ida-wtvp2-krzysztof-klopotowski-odpowiada-na-zarzuty-wymowa-filmu-jestniekorzystna-dla-polski-6025263394432129a [dostęp: 02.05.2018].

Ewelina Wejbert-Wasiewicz

\section{THE SOCIOLOGICAL PERCEPTION OF FILM AND CINEMA. ARTICULATIONS AND PRACTICES IN THE FIELD OF FILM AND CINEMA SOCIOLOGY}

\section{Summary}

The article attempts to reconstruct the field of the sociology of film and cinema based on a comparative analysis of important foreign and Polish works falling within the described subdiscipline. Among them are pioneering dissertations and research on cinema and film, sociological research programs, sociological studies, and studies devoted to the sociology of film and cinema. The main goal was to organise and summarise the heritage of the narrow discipline of film and cinema sociology, and to include certain practices, orientations and research trends. The author also showed the area of research devoted to film institutions as being poorly represented in the practice of sociological research in Poland and abroad. The theoretical inspiration for the explorations is Pierre Bourdieu's theory of scientific practice as well as the notion of habitus, field and capital.

Keywords: film sociology, sociology of cinema, film, cinema, cinematography 